\title{
Obstacles and Problems Facing the Financing of Small and Medium Enterprises in KSA
}

\author{
Osama Mohammed Elhassan \\ Department of Businesses Administration, College of Sciences and Humanities, Majmaah University, AL, Majmaah, Saudia Arabia
}

Email address:

oskapali@yahoo.com, o.hassan@mu.edu.sa

\section{To cite this article:}

Osama Mohammed Elhassan. Obstacles and Problems Facing the Financing of Small and Medium Enterprises in KSA. Journal of Finance and Accounting. Vol. 7, No. 5, 2019, pp. 168-183. doi: 10.11648/j.jfa.20190705.16

Received: February 17, 2019; Accepted: September 17, 2019; Published: October 26, 2019

\begin{abstract}
The current study dealt with the obstacles and problems facing SMEs in the Kingdom of Saudi Arabia. The study followed the descriptive analytical approach and found that there are multiple problems facing these institutions, the most important of which are the lack of funding, availability and capacity of employees, weak demand, government regulations and regulations in addition to some obstacles represented in fees. Labor and workers system recruitment, Competition, employment of Saudis, issuance or renewal of licenses, bureaucracy, and government measures. One of the most important findings of this study is the possibility of developing this sector in the presence of the General Authority for Small and Medium Enterprises, which relied on the division of institutions into three types (micro, small and medium) according to labor standards and revenue size. Through these results, the study recommends that the Saudi Arabian Monetary Agency (the Central Bank of Saudi Arabia) should have an encouraging policy for financing SMEs with a unified definition and a specific percentage of financing ceilings to be financed, with a legal and legislative basis and a mechanism for the development of SMEs. And to consider the establishment of banks specialized in the financing of these institutions to play their role in accordance with the Kingdom's vision 2030.
\end{abstract}

Keywords: Finance, Small and Medium Enterprises, Islamic Finance

\section{Introduction}

Various experiences and economic studies research in the field of obstacles facing SMEs are one of the most important engines of economic development. Those enterprises are considering one of the main pillars of economic renaissance in all economies of all kinds, developing or on the path of growth, planned or following free market mechanisms.

The conviction of the importance of large industries in economic and social activity remained dominant in economic thought until the mid-1970. However, this conviction soon changed in the mid-1970 with Professor" Schumacher" Small's Beautiful, Economic growth. In this paper, we will discuss in the first part, the theatrical concepts related to the SMEs and their preponderant role in the economy of the country. We will then discuss in the second part, the various obstacles facing those enterprises in Saudi Arabia.

\section{Definition and Concept of SMEs}

The definition of small and medium enterprises depends on the purpose of using this definition. However, there are universal definitions agreed upon by the organizations concerned.

\subsection{Definition of the International Labor Organization}

The "Small-scale enterprises are those units producing and distributing goods and services. Independent self-employed workers in urban areas of developing countries manage them. Some of them depend on work from within the family. Others may hire workers or artisans. Most of them with small fixed capital Very often, without fixed capital, using lowlevel efficiency, usually gaining irregular income, and providing unstable employment opportunities. Many of those enterprises are not registered with government agencies and that no data are available in official statistics [1].

The researcher notes that this definition was basing on the following criteria for distinguishing small enterprises:

1. It is an individual projects owned and managed individually for his account and this may be acceptable.

2. It works in urban areas - this does not correspond to the reality as it is spread in rural and urban areas. 
3. Its capital is very small without specifying a certain extent.

4. Low-level technology is used and this is acceptable.

5. Income is irregular and provides irregular employment opportunities, which is generally incorrect.

6. Most and, not all of those enterprises, fall within the informal sector.

\subsection{Definition of the United Nations Industrial Development Organization for Small Enterprises in Developing Countries (UNIDO)}

Based on the standard number of workers, "The small organization is composed of 15 to 19 workers. The medium is employing 20 to 99 workers and the large number of workers employing more than 100 workers [2].

\section{Standards Used in the Definition of Small and Medium Enterprises}

In fact, there is no agreed international definition of small and medium-sized industries. There is agreement on the criteria on which the different sizes of industry could be defined. The most common criteria are:

1. Number of employees: It is considered the simplest standards for definition and most common for ease of measurement and comparison in industrial statistics. The disadvantages of this definition different from one country to another, and do not take into account the technological disparity used in production.

2. Investment volume: The size of investment (capital invested) is a fundamental criterion in many countries to distinguish between small and medium industries and large industries, considering that the volume of investment gives a picture of the volume of industrial activity quantitatively.

3. Annual Sales Value: It can be considering as one of the criteria characterizing industries in terms of volume of activity and their competitiveness in the markets.

The following table 1. Illustrates the different criteria in identifying small and medium enterprises for selected countries.

Table 1. The different criteria in identifying small and medium enterprises for selected countries.

\begin{tabular}{lll}
\hline Country & Employment & Capital \\
\hline Malaysia & Less than 25 & 500 thousand rupees \\
Egypt & 35 & 100 thousand pounds \\
Germany & 49 & - \\
Singapore & Less than 50 & 250 thousand dollars \\
Ecuador & - & 200 thousand dollars \\
Japan & 100 & 28 thousand dollars \\
USA & 250 & Less than 9 billion dollars \\
United kingdom & 200 & Less than billion dollars \\
India & 100 & Less than 500 thousand rupees \\
Sudan & 30 & Less than 86 thousand dollars \\
Kingdom of Saudi & Less than 25 & Less than 10 million Saudi \\
Arabia & riyals \\
\hline
\end{tabular}

Source: Khalil and Nqmoush (2010) with the modification of the researcher.

Table 1 Shows the criteria used in the definition of small and medium industries in a number of countries. The Kingdom of Saudi Arabia relied on the number of workers to be less than 25 workers and the capital is less than 10 million Saudi riyals.

The table shows large differences in the size of the capital according to the country's economy. [3]

The researcher believes that the size of the capital is large because this classification includes three types of micro, small and medium enterprises. Also the researcher notes that some of the characteristics of SMEs are not relevant. However, the negative aspects of these projects are not directly relating to them, but are relating to the problems they are facing. What is to be emphasizing here is that small and medium enterprises can survive for a long time without making profits. They quickly collapse when faced with a critical cash payment that cannot be deferring. Therefore, direct cash flows are more important than profit or investment returns.

Islam Online (http://www.islamonline.net) reports that small projects can be classified in terms of field, objective, production systems or in terms of legal form as shown in the following form.

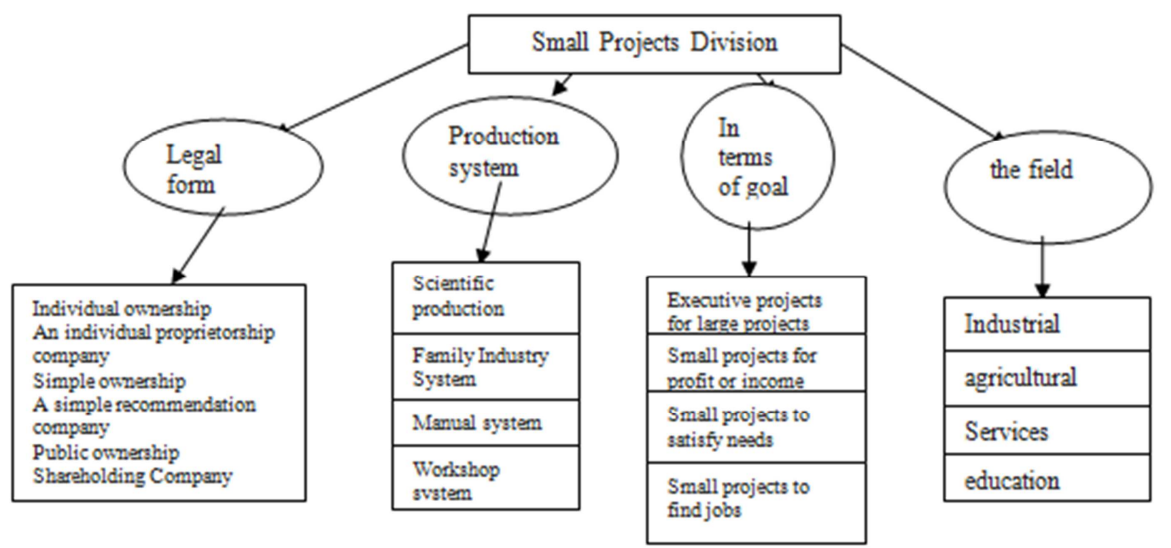

Source: http://www.islamonline.net.

Figure 1. Small Projects Division. 
Figure 1 above divides small and medium enterprises into four main sections: in terms of scope, objective, or nature of the production system and finally in terms of legal form [4].

\section{Importance of Small and Medium Enterprises}

It is important to emphasize that small enterprises occupy a great place in the economies of countries. It is the beginning of the economic activity that started with small projects before being big projects? They still occupy an important proportion even in the economies of the developed countries. Many economists believe that the development and promotion of small enterprises, as well as medium enterprises, are among the main sources of economic and social development in countries. Those enterprises are developing countries in particular, as a basic platform for increasing production capacity on the one hand and contributing to addressing the problems of poverty and unemployment on the other. Many States have therefore given increasing attention to these projects and have provided them with assistance and assistance in various ways and in accordance with the possibilities available. In view of the importance of these projects, most developing countries have concentrated their efforts on them. They have encouraged the establishment of small and medium industries, especially after having proved their ability and efficiency in dealing with the major problems facing different economies and larger industries. The investment volume is very low comparing to the large projects.

Arab Labor Organization report (2008) concludes that:" These projects have found various forms of care and support from the public and private sectors for their significant contribution to the industrial sector. For example, small and medium-sized enterprises are about $90 \%$ of the world's enterprises and employ about $50 \%$ to $60 \%$ of the labor force in the world. The most important obstacles facing the small and medium enterprises is the inability of their owners to provide the necessary funding for the continuity of their activities and their inability to provide guarantees. Traditional Commercial banks usually are contributing to a large projects and prefer to deal and lend to them because of the low risk of these projects on the one hand, and the ease with which banks deal with them on the other, and their ability to provide the required guarantees on the third hand.

The preferential treatment obtained by large industrial enterprises is considering the main motive for the development of loan risk's guarantee programs to facilitate financing for targeted SMEs. It enable them to obtain credit facilities by guaranteeing the risk of these loans with banks and financial institutions, For a wider segment of investors and entrepreneurs of economic feasibility who do not have adequate traditional guarantees, and this leads to the growth of these projects and their development and continuity. [5]

\section{The Economic and Social Importance of Investing in Small Enterprises}

The site of the journal Humanities (www.ulum.nl http://) dealt with the importance of small and medium enterprises" There is no doubt that the economy of countries depends heavily on investment in large institutions, which are often public sector, as they contribute effectively to economic development. However, these investments need investments in small and medium enterprises, whether in the provision of raw materials or in the comprehensive marketing. This is necessary to meet the needs because it is not logical to cover the market, such as the needs of milk production plants and its derivatives to the breeders in the provision of raw material, as well as the need for retailers to sell their sales. So, it is clear that the need for the type of investment to the important role which plays in economic development through:

1. Reducing unemployment and providing jobs.

2. Providing raw materials for large investments in most cases.

3. Disposal of products of large enterprises.

4. Helping to increase the volume of sales and distribution, which reduces storage costs.

5. Absorbing the benefits of idle funds and savings and work to operate and participate in the profits

6. Training and building a leadership class in societies and increase their efficiency.

7. Renewing in the services and products provided.

8. Exploiting the local wealth.

9. Eliminating monopoly and achieving regional balance. [6]

The Small-cap investments have a significant impact on the way of life of communities and have a direct impact on their daily lives. They improve living conditions by raising per capita income and reducing widespread social pests. The interdependence of the members of society is achieving through the relationships that arise between their employees, and the systematic thinking of the society. It affects the behavior of its members and it reflects in the social role of this type of investment. The most important characteristics of investments in small businesses are:

1. Lower required capital requirements, small loans required and risks involved.

2. The existence of a limited market and a distinct number of consumers, allowing quick coverage of the market.

3. Lack of the size of the necessary workforce and the achievement of team spirit and relatively low costs.

4. The simplicity of using of the technology used.

5. The existence of simplified work procedures and clear plans.

6. Reducing the cost of management and public expenses.

7. Freedom and flexibility in entrance and exit from the market.

8. Speed and accuracy in decision-making and lack of 
routine.

9. Speed in changing activity. [7]

Omar (2009) said that "Speaking of economic and social benefits means essentially:

1. Creating large employment opportunities with limited investments, which will help to alleviate the unemployment problem and address the poverty situations prevalent in developing countries.

2. No need for large capital. Financing is often local and depends on local requirements, which does not need foreign currency to increase the balance of payments deficit, as well as contribute to the self-sufficiency of goods and services rather than importing from the outside.

3. These projects are using technology that is less suited to local conditions and does not require the importation of technology from developed countries.

4. The possibility of exploiting any area of residence and simple equipment, which reduces the low costs of infrastructure.

5. It is flexible in its work, processes and products.

6. It aims to localize industry in urban and rural areas, thus achieving sufficient stability and balanced distribution of population between rural and urban areas.

7. It plays an important role in feeding the large industries with some of the necessary inputs for production at a lower cost than if they were produced in the large factory.

Despite the previous advantages, there are several problems facing these projects. Omar (2009) concluded these problems as follow:

1. Lack of official funding because of their inability to deal with official financial institutions.

2. It can only deal with informal financing institutions under difficult conditions. The interest rates and the low level of funding can be obtaining from these institutions and short-term, which cannot finance fixed capital.

3 . The difficulty of formal registration of multiple procedures and the inability to meet the official conditions for registration and the high costs of registration.

4. Pursuit of official organs for most of them without licenses.

5. The difficulty of marketing their products because of their inability to access the appropriate markets.

6. Inability to grow and lack of organizational experience. [7]

There is a strong reliance on the importance of small and medium-sized enterprises (SMEs) as a source of entrepreneurship and innovation. New small industries are innovating new products and processes, often small in size and starting to grow rapidly if successful. The small and medium-sized enterprise in the industrial sector has taken the lead in the technological field not only in the use of modern advertising techniques, but also in the use of machinery and equipment that are most appropriate and appropriate to the sector in which it is located. [8]
The importance of SME contribution to the economic and social development process is attributed to the following reasons:

1. Small and medium-sized enterprises (SMEs) depend on the intensive labor and tend to distribute income more fairly than large enterprises. They play an important role in creating employment opportunities that reduce poverty. They often provide more work opportunities for workers from poor families and women.

2. Small and medium-sized enterprises contribute to raise the efficiency of resource allocation in developing countries. They tend to adopt labor-intensive methods of production, reflecting their labor force and capital scarcity. As these projects expand in informal markets, the prices of the factors of production and the products they deal with reflect better the costs of alternative opportunities than the prices of large enterprises.

3. Small and medium-sized enterprises support the building of comprehensive productive capacities. They help to absorb productive resources at all levels of the economy. They contribute to the establishment of dynamic and flexible economic systems in which small and medium-sized enterprises are interconnected. They also expand in a larger geographical area than large enterprises. In addition, it helps reducing development gaps between urban and rural areas.

According to a study presented at the Riyadh Chamber of Commerce and Industry within the Riyadh Economic Forum on Sustainable Economic Development (2004), Small enterprises occupy an important and growing position in industrialized and developed countries through their participation in:

1. Renewing, innovating and increasing the productive efficiency of developing export capacities in foreign markets and strengthening the competitive position of developed countries towards other countries, especially the newly industrialized countries (East and South East Asia).

2. Improving the efficiency of large companies by reviewing the size of their production units and dividing them into small units with higher efficiency and strengthening their backward and forward ties with the parent companies.

3. Providing many new job opportunities to reduce the problem of unemployment caused by the rapid spread of technology in various economic sectors.

4. Increasing foreign direct investment and enter into joint ventures in host countries, rather than relying exclusively on transnational companies (large scale) and on export and licensing systems that face difficulties under existing economic and regional blocs.

5. Meeting the increasing demand for services resulting from improved incomes and living standards resulting from improved income and living standards, such as installation, repair and maintenance services, as well as demand for specialized consumer goods that are influenced by individual tastes and preferences. [9] 
The following are some quantitative indicators that reflect the relative weight represented by small enterprises in developed industrial countries.

Table 2. The relative importance of small industrial enterprises in some industrialized countries.

\begin{tabular}{|c|c|c|c|c|}
\hline Country & Number of establishments & Employment & Production & Exports \\
\hline USA (1982) & $90 \%$ & $28 \%$ & $21 \%$ & - \\
\hline UK (1988) & $95 \%$ & $34 \%$ & - & - \\
\hline Japan (1983) & $97 \%$ & $56 \%$ & $34 \%$ & - \\
\hline South Korea (1982) & $91 \%$ & $33 \%$ & $16 \%$ & - \\
\hline
\end{tabular}

Source: C. L. Mann (1990).

From the above table we find that the contribution of small and medium enterprises in the economies of the developed countries is very large, about $86 \%$ in the Netherlands, $90 \%$ in the USA, 91\% in South Korea, 95\% in the UK and the highest contribution was $97 \%$ in Japan. [10]

The researcher notes that the previous data compared to different years may be due to lack of data for one year.

In developing countries, small enterprises gain their importance from a combination of considerations regarding the characteristics of their economic and social structures, the availability of factors of production, the spatial distribution of populations and economic activity. The most important positive phenomena associated with the small business sector and repeated in most economic literature can be summarizing as follows:

a) Small enterprises use relatively simple productivity, characterized by high labor intensity, which helps developing countries cope with the problem of unemployment without incurring high capital costs.

b) Small enterprises are characterized by geographical dispersion, which helps to reduce regional disparities, achieve balanced spatial development and serve limited markets that do not entice large enterprises to settle or deal with them.

c) Small enterprises provide goods and services to lowincome groups of society that seek them at relatively cheap prices consistent with their purchasing power.

d) The small business sector offers many opportunities for working for some groups particularly women, youth, and the mass of displaced people from rural areas that are not yet qualified to join the large business sector and the formal sector in general.

e) In view of their small investment requirements and the simplicity of their production techniques, small businesses may be more efficient than large enterprises in mobilizing and employing local savings and developing human skills, and thus can be considering as an important source of capital formation and a conduit of organizational skills and a laboratory for new activities and industries.

f) Small enterprises play an important role in supporting large enterprises through the distribution of their products and supply of inputs of production.

g) Small enterprises help to exploit the wealth resources scattered in limited quantities in remote locations, which usually fail large enterprise to detect and commercial exploitation.

h) The small enterprise contributes to the diversification of the economic structure through its various and varied activities. It also helps to change the market structure by reducing concentration and increasing the degree of competition between the production and service units.

i) Small enterprises are more efficient in using capital, which is confirmed by some applied studies in Kenya, India, Egypt and other countries by comparing capital productivity in enterprises of different sizes and return on investment in each of them.

j) Small enterprises play an important role in the development of secondary cities, which helps to alleviate the urbanization and excessive urbanization of capitals and major cities. [11]" Small enterprises contribute to the promotion of labor-intensive exports in many developing countries, such as India, Taiwan, Korea, the Philippines and Singapore.

Table 3. Contribution of small enterprises to the GDP of some countries.

\begin{tabular}{lll}
\hline Country & Small size enterprises & Contribution of small enterprises to GDP \\
\hline Kingdom of Saudi Arabia & $92.7 \%$ & $28.7 \%$ \\
Japan & $99.4 \%$ & $56.3 \%$ \\
India & $92.1 \%$ & $39 \%$ \\
Singapore & $97 \%$ & $70 \%$ \\
Egypt & $96 \%$ & $76 \%$ \\
Tunisia & $92 \%$ & $53 \%$ \\
\hline
\end{tabular}

Source: SALAMA (2009).

The table 3 above shows that the size of small and medium enterprises in the Kingdom of Saudi Arabia is about $92.70 \%$ and its contribution to the GDP is $28.70 \%$. This is a low percentage compared to the rest of the countries in the table, whose contribution ranged from 39\% in India to $76 \%$ in Egypt. Al-Beltagy (2005) spoke about the importance of small 
enterprises in achieving economic and social development. "Many people interested in small enterprises discussed the importance of small enterprises and the important role they play in economic and social development as follow:

A. The ability of small enterprises to provide employment: It is estimating that the cost of permanent employment in large industries cost about $\$ 15$ thousand, while in small enterprises it costs between $\$ 900-\$ 3000$, which contribute to the absorption of different disciplines and contribute to the treatment of unemployment.

B. Supporting domestic output: Small enterprises play an influential role in supporting domestic output because they are an effective tool in expanding the production base when implementing export support and import substitution strategies, which helps to address the structural imbalances of balance of payments, especially in developing countries.

C. Small enterprises contribute to the distribution of wealth, justice and the narrowing of the gap between the poor and the rich, a principle urged by Islam.

D. Small enterprises are tributaries to feed large industries with production inputs. International companies are currently relying on small industries to produce the main components of their production lines, which in some industries constitute more than $75 \%$ of the main component, thus contributing to the development of small enterprises.

E. Small-scale enterprises are the main core of large enterprises in the future, developing and growing at high rates.

F. Small businesses help meeting the needs and demands of consumers by diversifying products to suit those needs and tastes. [12]

\section{Role and Contribution of SMEs in National Economies}

The role and contribution of SMEs in the economy is measuring by three main criteria: contribution to employment, production and share of the total number of enterprises in the economy. The main advantages of these facilities are as follows:

a) Small and medium-sized enterprises provide a potential source of competition for large enterprises and limit their ability to control prices.

b) These facilities are the main source of employment in both developed and developing economies.

c) These facilities are essential seeds for large projects.

d) These projects are characterizing by providing an appropriate working environment where the entrepreneur and the workers work side by side for their mutual benefit.

e) This type of projects helps in the development of the less fortunate areas of growth and development and low levels of income and high unemployment rates.

f) These projects are fertile areas for the development of innovations and serious ideas.

\section{Financial Needs and Obstacles of Small Projects}

Published in the Journal of the Chamber of Commerce and Industry of Hama, Syria (2002), a study stated that "small projects pass when they are established in several phases, and the forms of funding vary according to the stage in which they pass:

a) Foundation stage: Usually by the family.

b) The initial growth stage: self-generated through the profits that are invested.

c) Accelerated growth: The owner can borrow money from banks, using some organizations that help him to provide guarantees as an organization, which reduces the cost of capital.

d) If the project requires a new investment to expand its business or to diversify its products, the financing can be providing by government agencies or the like.

e) The cost of borrowing money can be reducing by issuing a number of laws for companies with a particular classification or operating in a specific geographic location.

f) Banks are the source of funds, which provide short-term financing. Sometimes the debts of previous projects can be scheduled and consolidated to increase their working capital over the medium term. It is essential that the banking system take into account the economic and social environment of the existing financial community.

In our country, it is possible to establish banks that take into account the rules of Islamic law because many people refrain from dealing with conventional banks for legitimate reasons, which deprives their work of this type of funding, despite the need. In addition, Islamic banks use more flexible and productive tools than the interest system that burdens debtors, such as Musharaka, The role and contribution of SMEs in the economy is measuring by three main criteria: contribution to employment, production and share of the total number of enterprises in the economy. The main advantages of these facilities are as follows, that ends with ownership, leasing, leasing, Murabaha, etc". [13]

According to Ibrahim (2007), "The difficulty of obtaining bank loans is one of the obstacles facing the financing of small and medium enterprises, and there are signs of poor access to financial resources in the financial sector organized by enterprises,". The lack of financial resources that some project owners tend not to optimize their financial resources. However, some of them were able to exploit their poorly resourced financial resources. Small and medium-sized enterprises (SMEs) have high rates of return on capital invested compared to large projects.

Moreover, SMEs are characterizing by higher total productivity and overall economic efficiency, represented by the high rate of production of invested capital. The return on capital of small enterprises as compared to large enterprises 
demonstrates the eligibility of SMEs for financing depending on the economic efficiency of capital. There is an important fact: the less capital, the greater the return on capital and vice versa. The high rate of return on capital in SMEs is in fact a better guarantee than traditional guarantees, which are not available to owners of small and medium enterprises."

Ibrahim (2007) confirm that "Many of the financing hurdles for SMEs are caused by the high cost of financing the cost of managing and extending loans and the cost of not being able to pay,". Banks, the owners of small and mediumsized enterprises are dangerous customers, and they do not regularly keep documents as desired by the banking system. Therefore, they cannot meet the requirements of traditional guarantees. A general observation is that there is no serious attempt to adapt the banking system to meet the needs of SME clients. This means that there are no innovations by commercial banks to manage microcredit. The experience of sharing profits and losses can be considering as an advanced step towards achieving the objective of formulating banks to meet the requirements of small loans. There is a general observation that there is no serious attempt to adapt the banking system to meet the needs of SME clients. [14]

Yassin (2008) confirm, "In Sudan, small and handicraft industries count for more than $90 \%$ of the total number of industrial units, referring to the constraints facing small enterprises in Sudan. On the part of their owners (such as family business) will soon weaken and disappear after one or two generation. The obstacles to the growth of small and handicraft industries in Sudan are attributing to several factors. There are administrative and regulatory obstacles that make the flow of credit loans needed by small industries to capitalize (capital goods) and finance working capital necessary for employment is almost impossible from the point of view of financial institutions represented in:

1) Small industries are not adopting for accounting systems and systems for keeping information about their production and consumption of raw materials. This makes the task of carrying out feasibility studies in this field not easy, which makes it difficult to identify the strengths and weaknesses of these units.

2) The lack of collateral required by banks such as real estate mortgage. Most owners of small industries and craft do not have the property can be mortgaged and work in shops on the basis of rent.

3) Different nature of the circumstances surrounding the small work and the difference between each other, and the difference between the one craft. This makes the development of standard indicators that can be generalizing to several craft activities when studying for financing, a difficult and expensive and slow subject. Because in this case, it is inevitable to study each case separately.

Administrative and regulatory were developing outside the jurisdiction of financial institutions because of lack of funding conditions. Yassin (2008) goes on to "But as we look at the development of the small and handicraft production sector, we find that the main factor of all its problems, which keep it away from development and the great obstacle that is blocking the windows of expansion, is the weakness of its equity capital base. The validity of small and professional industrial units for bank financing is the loss of these units of capital that can contribute to any financing process for the enrichment of productive goods (machinery and equipment). As mentioned earlier, most of these units lack the assets to meet their contribution to financing operations at the level required by banks. In order to circumvent this problem, the international financial institutions (IFC), such as the International Finance Corporation (IFC), have solved the problem. The solution lays in the creation of capital funds in poor countries (with promoters), national banks and other financial institutions loans, but to contribute to the capital of those units. The program was followed by regional finance institutions such as the African Development Bank and the Asian Development Bank (Venture capital funds). This idea was derived from the experience of the emergence of venture capital or gambler that began in Western industrial countries in the early sixties of the last century along with the technological revolution in the field of computer, electronics and information technology. The purpose of this type of financing (gambling) is to contribute to small companies working in the above-mentioned areas and turning them into ideas for big companies (Microsoft example). The main issue for banks and financial institutions that create these funds is the exit strategy of these units at the right time either through direct selling to other investors or by listing on stock exchanges as a policy of exit from investments through the sale of shares. The common banks in these funds are the liberalization of their capital and the liquidity they need in their various banking operations in line with the nature of their work. However, in poor countries, especially in Africa, including Sudan, where are the primary and secondary financial markets that are active and sophisticated that enable banks to securitize or securitize their capital in small production units?

The researcher believes that there is a governmental interest in the small industries, which has become evident in recent years. A small industries department has been establishing in the Ministry of Industry. Its duties and responsibilities are in implementing the state policy of supporting, encouraging and developing small industries in terms of legal organization, conducting technical and diagnostic studies, Assistance for the establishment of small industries and the establishment of cooperative relations and coordination with trade unions and professional and other. [15]

\section{Reasons for Conventional Banks' Reluctance to Finance Small Businesses}

Al-Beltagy (2005) said, "One of the main reasons for the reluctance of conventional banks to finance small enterprises is the following:

\subsection{Inadequate Criteria for Lending to Small Enterprises}

Banks set many criteria and conditions that met in establishments that can receive funding and these standards 
and conditions are not often compatible with the nature and characteristics of small enterprises.

\subsection{Weak Financial Structures of Small Enterprises}

Where banks put many of the ratios and financial indicators extracted from the financial centers of enterprises such as operating advantage rates and the proportion of expenses for income and profitability rates to other credit indicators, which is not often available in those establishments to determine the creditworthiness and then reluctance of those banks to finance these facilities.

\subsection{Weakness of Guarantees}

Guarantees are one of the most important elements of granting credit in banks. In practice, small enterprises do not have the necessary guarantees for financing. Consequently, banks are reluctant to finance these facilities due to lack of adequate guarantees for granting funding.

\subsection{Irregularity of Accounting Records}

Banks rely on the granting of credit on the study of financial records and regular final accounts approved by accredited auditors, which is not available in the majority of small enterprises, most of which prefer not to keep regular books of weak potential and reduced volume of activity, Personal statistics, and some avoid tax problems.

\subsection{The Inability to Prepare a Credit File}

Many small enterprises lack the banking experience and the ability to prepare a file can be providing to banks to obtain the necessary funding, where preparing the file in accordance with the correct banking norms of the criteria for obtaining the necessary funding.

\subsection{Lack of Sound and Objective Feasibility Studies}

One of the most important requirements of banks to grant credit is a feasibility study of the facility to be funded, and often-small enterprises do not have feasibility studies at the required level due to the high cost of preparation. It sometimes reaches high numbers that owners of small enterprises cannot provide.

\subsection{High Risk}

Most of the small enterprises are characterizing by high risk due to the nature of their composition, which depend on the majority of one person or a single family in addition to the weakness of financial centers. It represents an obstacle for the banks to finance these facilities where banks are always interested in financing low risk enterprises. The field study found that the risk of small enterprises ranged from medium to high risk.

Lack of supporting bodies for these establishments: The majority of small enterprises are individual and the lack of supporting entities. The work on the organization of their work and development has been shown from the field study the importance of the existence of supporting bodies of those establishments. Whether official bodies or affiliates such as the Guarantee Fund Social Development Fund in Egypt and the Industrial Development Fund in Saudi Arabia.

High interest rates on loans: Interest rates and terms of repayment of loans are one of the main obstacles to the demand of small enterprises to obtain funding from banks, especially in the initial years the margin of profitability is a bit of which cannot pay the loan installments as well as benefits, the problems.

The inadequacy of traditional bank financing formulas for small enterprises: Most small enterprises require medium and long term financing for construction and investment purposes. This is not in line with the criteria for granting bank financing, which always prefer to grant short-term loans that are commensurate with the nature of most banks' financial resources.

The weakness of the accumulated experience of the owners of small enterprises: The field study shows that one of the most important obstacles to granting financing to small enterprises is that the managers lack the practical experience to manage these facilities and deal with changing market data.

Al-Bataji (2005) adds that the forms of interest-based financing are not suitable for small enterprises for several reasons:

1. The high cost of financing compared to the average return on the money invested from the project, and this leads to loss or stop.

2. Modest experience in the management of small enterprises sometimes exposed to the risks of both technical and marketing difficulties to insure against them.

3. The difficulty of providing adequate guarantees to repay the loan and its benefit from small business owners because most of them are young and poor.

4. In addition to the above, traditional banks are often forced to provide subsidized financing (low financing cost) for small enterprises.

\section{Practical Framework of the Study}

The study attempts to present the practical framework that was based on the results of the questionnaire prepared for the study in addition to the results of the survey of small and medium enterprises for 2017 conducted by the General Organization for Statistics.

\subsection{Study Framework}

This study deals with small and medium enterprises in the Kingdom of Saudi Arabia and the obstacles and problems faced by them. It deals with a sample of small and medium enterprises in Riyadh, which represents about $25 \%$ of the number of small and medium enterprises in Saudi Arabia according to the report of the General Authority for Statistics for 2017. Consequently, the outputs of this study do not apply to SMEs outside Saudi Arabia. 


\subsection{The Study Sample}

The results of the 2017 Small and Medium Enterprises Survey were based on the selection of a sample of 158 small and medium enterprises distributed as follows:

Table 4. The distribution of the research sample on small and medium enterprises according to the type of economic activity.

\begin{tabular}{lll}
\hline Economic activity & Numbers & Ratio \\
\hline Wholesale and retail trade & 77 & $48.73 \%$ \\
Manufacturing & 43 & $27.21 \%$ \\
Accommodation and food & 19 & $12.03 \%$ \\
Agriculture and fishing & 12 & $7.60 \%$ \\
Other & 7 & $4.43 \%$ \\
Total & 158 & $100 \%$ \\
\hline
\end{tabular}

Source: Preparation of the researcher from the reality of field study 2018.

Table 4 shows the distribution of the sample of research on small and medium enterprises by type of economic activity. Their distribution was as follows: Wholesale and retail trade was 77 companies with $48.73 \%$, followed by manufacturing industries with 43 establishments with $27.21 \%$ The total number of establishments in the field of agriculture and hunting reached about 12 establishments with percentage of about $7.60 \%$. Finally, the other institutions and 7 institutions of the total research sample of about 158 establishments reached about $4.14 \%$.

\subsection{Data Collection}

The questionnaire was distributed to the research sample and the information was collected directly by the researcher either by direct responses or via e-mail, and the links of the questionnaire or direct visits.

\subsection{The Methodology of the Study}

In this study, we use the descriptive and analytical approach that is relevant with the nature of the study. We have been relying on the preliminary information through the questionnaire and interviews with banks and the and secondary information was collected through periodicals magazines and various references.

\subsection{Definition of SMEs and the Criteria Used}

Small and medium-sized enterprises (SME) financing is associated with a specific definition of small and mediumsized enterprises (SMEs) through the interview. Such a definition has been found in banks. Small enterprises are defining as those with fewer than 10 employees. The average institution is an institution with more than (10) Workers and less than fifty (50) workers.

\subsection{Small and Medium Enterprises in Saudi Arabia}

According to the Arab SMEs consultant, Small and medium-sized enterprises play a major role in enriching economic activity and achieving macroeconomic goals. "Small and medium enterprises in Saudi Arabia are supposed to play an important role in achieving economic objectives. It helps to achieve economic growth. The competitive economy is not basing on the existence of giant companies and large alone, but on the attractive environment for entrepreneurial work. It provides a wide network and a variety of suppliers of small enterprises able to meet the needs of large companies [16]".

Small and medium-sized enterprises in the Kingdom account about $93 \%$ of the total registered companies and absorb about $27 \%$ of the total employment. However, their contribution to GDP is only $33 \%$, which is a weak contribution to the size of the Saudi economy and the Kingdom's focus on economic diversification. SMEs contribute at least by $50 \%$ of GDP. The Kingdom of Saudi Arabia has been keen to strengthen the SME sector and increase its number during the last few years, especially with a high rate of growth. The population growth rate in the GCC countries is one of the highest in the world at $3 \%$ of the importance of supporting small and medium-sized enterprises stems from a basic set of economic data. The conditions should provide adequate job opportunities for job seekers. The medium and large enterprises contribute to supporting the national economy by diversifying sources of income and expanding the productive base. It also integrates economic activities and balance in the process of economic development and economic stability. It also contributes to the development of local skills and technology. In general, small and medium enterprises are the most capable tool to eliminate the phenomenon of unemployment and poverty in society.

\subsection{The Most Important Problems Faced by Small and Medium Enterprises in the Kingdom of Saudi Arabia}

Several studies have confirmed that small and medium-sized enterprises face difficulties such as weak financing by banks, tightened guarantees and limited options for small enterprises. Many of them do not have assets to prove their financial problems. the Journal of the Consultant of Small and Medium Enterprises Reported http://smeadvisorarabia.com. The "number of small and medium enterprises in the Kingdom has increased recently, but only $71 \%$ of these establishments are operational and $29 \%$ are closed due to the financial problems. Reports indicate that the number of individual establishments out of the total number of establishments operating is about 688 thousand, or about $85 \%$ on the total operating establishments.

The researcher believes that there is a governmental interest in the small industries. The establishment of the General Authority for Small and Medium Enterprises (SME) was established. The responsibilities are to implement the State's policy of supporting, encouraging and developing small industries in terms of legal organization, conducting technical and diagnostic studies.

\subsection{The Reality of Small and Medium Enterprises in the Kingdom of Saudi Arabia}

The Saudi General Organization for Statistics conducts an annual survey of small and medium enterprises. The survey 
aims to:

1. The extent to which SMEs contribute to the output.

2. Provide data that helps to know the rates of growth and continuity of SMEs for each economic activity.

3. Know what each economic activity absorbed from the number of employees.

4. Know the size of the change in the compensation of the employees who are paid according to the economic activities.

5. Identify the size of expenditures and revenues for each economic activity.

6. Know the most important obstacles that prevent the continuity of enterprises in the labor market.

7. Provide data on the utilization of electronic systems and services in small and medium enterprises [17].

The following table 5 shows the number of SMEs in Saudi Arabia according to the type of economic activity year 2017.

Table 5. Shows the number of SMEs in Saudi Arabia according to the type of economic activity year 2017.

\begin{tabular}{lll}
\hline Economic activity & Numbers & Ratio \\
\hline Wholesale and retail trade & 452932 & $47.70 \%$ \\
Manufacturing & 103652 & $10.90 \%$ \\
Accommodation and food & 100282 & $10.60 \%$ \\
Agriculture and fishing & 94601 & $10.00 \%$ \\
Collective and personal services & 67358 & $7.10 \%$ \\
Construction & 30864 & $3.20 \%$ \\
Real Estate Activities & 28076 & $3.00 \%$ \\
Professional and technical activities & 24669 & $2.60 \%$ \\
Transport and storage & 15419 & $1.60 \%$ \\
Other & 31978 & $3.3 \%$ \\
\hline
\end{tabular}

Source: Preparation of the researcher from the reality of field study 2018.

According to Table 5 above, the number of SMEs reached about 950 thousand in 2017. And about half of these establishments are $47.7 \%$ engaged in wholesale and retail trade, $10.9 \%$ are in the industrial sector, $10.6 \%$ are in the field of accommodation and food, $30.8 \%$ are engaged in other activities.

The number of employees in these establishments was 4.72 million, $78.6 \%$ of whom were foreigners. The percentage of Saudis employed was $21.4 \%$. The percentage of Saudis working in wholesale and retail trade was about $35.9 \%$. The researcher believes that the SME sector can play a bigger role in providing job opportunities for Saudis.

Figure 2 below shows the number of SMEs in Saudi Arabia by type of economic activity for 2017.

\subsection{Kingdom Vision 2030 for Emerging, Small and Medium-sized Enterprises and Productive Families}

Vision 2030 is mentioned in this regard "Small and medium enterprises are the key drivers of economic growth, creating jobs, supporting innovation and boosting exports. Small and medium-sized enterprises (SMEs) contribute a low share of GDP compared to developed economies. We will seek to create suitable employment opportunities for citizens throughout the Kingdom by supporting entrepreneurship, privatization programs and investment in new industries. In this regard, we have established the General Authority for Small and Medium Enterprises (SMEs). We will continue to encourage young entrepreneurs to succeed through better regulations and regulations, easier financing, and greater international partnerships for local companies from government procurement and competition. We will support the productive families that have provided the means of modern communication and broad marketing opportunities through facilitating opportunities for financing microenterprises, and stimulate the non-profit sector to work on building the capacity of these families and funding their initiatives".

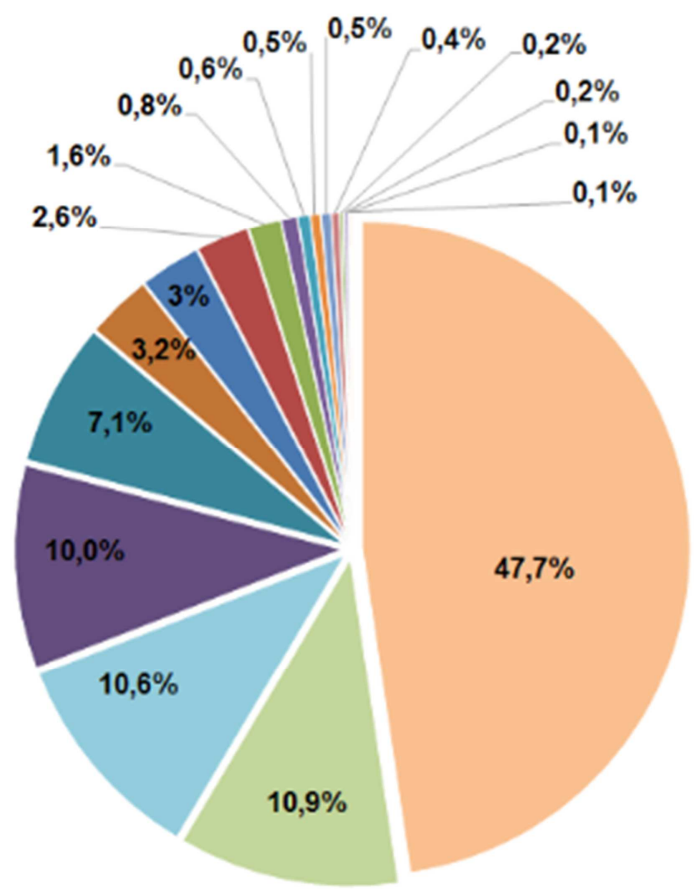

Figure 2. Number of SMEs in Saudi Arabia by type of economic activity for 2017.

Source: Survey of the General Organization for Statistics for Small and Medium Enterprises (2017).

The Kingdom's Vision 2030 continues to underscore the interest of small and medium enterprises (SMEs). "Small enterprises contribute only 20per cent of GDP compared with 70 per cent in advanced economies. Small enterprises in Saudi Arabia continue to suffer from the complexity of regulatory and administrative procedures and their slow pace, weak capacity to attract talent, and difficulty in obtaining finance. Small and medium-sized enterprises (SME) account for only $5 \%$ of total funding, to an assistant and to urge our financial institutions to increase this percentage to $(20 \%)$ by the year (1452H - 2030G) with the help of God. The newly established Small and Medium Enterprises Authority will seek to review regulations and regulations, remove barriers, facilitate access to finance, and help young people and innovators market their ideas and products. At the same time, we will seek to create more business incubators, training institutions and specialized venture capital funds to help entrepreneurs develop their skills and innovations. We will 
also help small national enterprises to export their products and services and market them by supporting e marketing and coordinating with international stakeholders. [18]

Add a website http://smeadvisorarabia.com "The logistical support of the youth of these projects and their assistance in drafting contracts, starting the project, identifying the many procedures of the government and avoiding the expected obstacles of any project in its infancy are the first steps required by the Authority and its Governor to start work on them. To recognize the obstacles and beginnings of the beginnings and gain the experience and confidence that helps him to manage things himself later.

The second support required is to market the products of these projects. It is not difficult to get a government loan and start production, but the most difficult and most important is marketing. A young person who started a new project is not expecting to have marketing skills or a public relations network that will help him to market what is producing. The Commission should support the marketing of SME products; seek to make the purchase of the products of these enterprises a condition for obtaining government project contracts, and to work with large companies such as Aramco, SABIC and the banks to buy the facilities they need. It is also possible to take advantage of social networks to encourage people and encourage them to buy products and support these projects, because of the national goals that benefit the community and employ its youth.

The third support is through the exploitation of the relationship with the chambers of commerce and business communities to lend a hand, adopt the projects of these young people, and support them with their experiences and relationships, such as the mentor or mentor in the West (Mentors) for young and beginners in business.

Fourth and important support is the need to agree with the Ministry of Labor to exclude these projects years of any change in the policies and conditions of the ministry. It is noted that the Ministry has every day a policy, decision and additional fees, which is not borne by small and new projects, and must be excluded from any change that hinders its development and development to strengthen its return and increase with time, and then the decisions can be applied after the exclusion of time.

The fifth support is to strengthen the competition of these establishments in the internal market. It enables them also to take their hand for external export, and internally to prevent the foreign labor groups that are covered by them.

The sixth and final support is to promote so-called family projects, and seek to involve more than one person from one family in a single project. The well-known business families with large projects in the country today have started small family businesses, developed and developed them, and there are countries that have a good experience of this kind that can benefit from their experiences to support the family economic activity in the Kingdom [23]".

\subsection{The Most Important Problems Faced by Small and Medium Enterprises in the Kingdom of Saudi Arabia}

According to the General Organization for Statistics, based on the survey of small and medium enterprises for the year 2017, the most important problems facing these institutions are listed in the following table 6 .

Table 6. Percentage of establishments according to the most important problems facing them classified by size.

\begin{tabular}{|c|c|c|c|}
\hline Problems & 1-5 employees & 6-49 employees & 50-250 employees \\
\hline Low Demand & $16 \%$ & $13 \%$ & $16 \%$ \\
\hline Marketing/Export & $6 \%$ & $5 \%$ & $6 \%$ \\
\hline Availability \& Capability of Labor & $21 \%$ & $18 \%$ & $21 \%$ \\
\hline Availability of Finance & $13 \%$ & $14 \%$ & $13 \%$ \\
\hline Availability of Raw Material & $9 \%$ & $6 \%$ & $9 \%$ \\
\hline Local Competition & $13 \%$ & $14 \%$ & $13 \%$ \\
\hline Foreign Competition & $13 \%$ & $4 \%$ & $13 \%$ \\
\hline Government Systems \& Regulations & $9 \%$ & $9 \%$ & $10 \%$ \\
\hline General Services & $7 \%$ & $5 \%$ & $5 \%$ \\
\hline Machinery/Equipment \& Technology & $13 \%$ & $10 \%$ & $6 \%$ \\
\hline
\end{tabular}

Source: Survey of the General Organization for Statistics for Small and Medium Enterprises (2017).

Table 6 shows the percentages of establishments according to the most important problems faced by the size. It is clear that the most important problems faced by institutions with less than five workers are the problem of financing by about $25 \%$ of the total number of institutions. The problem of the third, according to the above table, is the problem of weak demand, which amounted to $13 \%$. The percentage of problems related to government regulations and regulations was about $10 \%$. The problems related to customers and collection was about $7 \%$. The percentage of problems related to technology Machinery about $6 \%$ equal $\mathrm{m}$ The proportion of problems associated with local competition, the problem of public services increase amounted to about 5\% immediately followed by the problem of availability of raw materials by $3 \%$, and the percentage of problems related to marketing and export about $2 \%$ of the total number of institutions and finally was the problem of foreign competition, which amounted to $1 \%$.

In terms of establishments with a labor force of 6-49 workers, the biggest problem was the problem of availability and capacity of workers, which amounted to about $18 \%$. The problem of availability of finance and local competition was in second place with about $14 \%$ the fourth place was about $13 \%$, and the machine and technology company ranked fifth 
by about $10 \%$. The sixth and seventh rank in terms of problems facing enterprises with a number of employees between 6-49 were the problems of customers and collection and problems of government regulations by $9 \%$ For each, And in the eighth place came the problem of the availability of raw materials by $6 \%$ The ninth problem facing these institutions were represented in public services by $5 \%$ and the problem of marketing and export by the same proportion and finally problems related to foreign competition about $4 \%$.

As for enterprises with 50-250 workers, the problems faced by workers were $21 \%$, followed by the problem of weak demand (16\%). The problems related to finance, machinery, technology, competition, the problems related to the local regulations and the problem of availability of raw materials and customer problems and collection amounted to $9 \%$, while the problems of public services amounted to $7 \%$, and finally the problems related to marketing and export by $6 \%$ from the previous table 6 . We find that these institutions and their three classifications face similar problems:

1. Lack of funding.

2. Availability and capacity of employees.

3. Weak demand.

4. Government regulations and regulations.
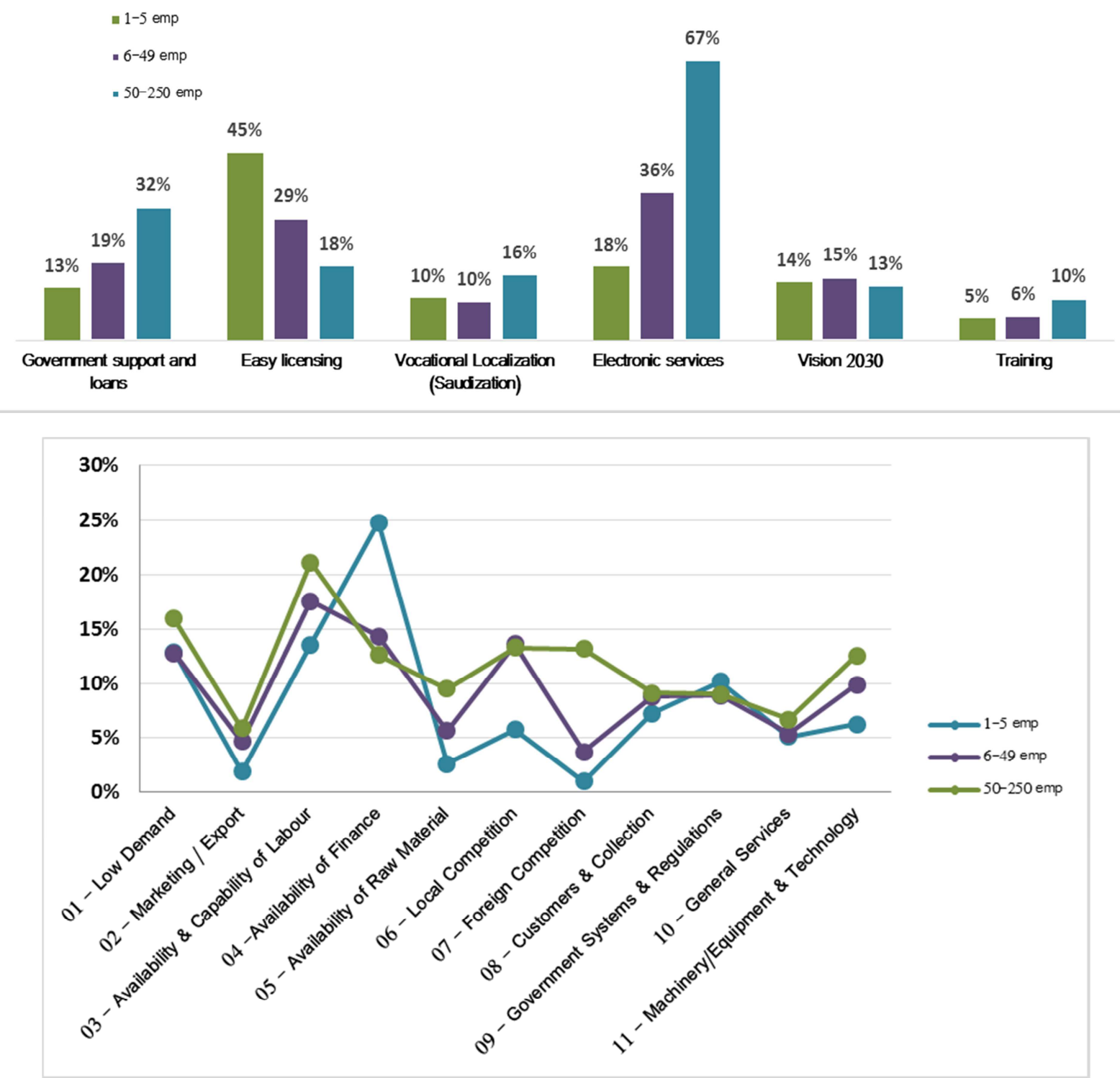

Source: Survey of the General Organization for Statistics for Small and Medium Enterprises (2017).

Figure 3. Percentage of establishments according to the most important problems facing them classified by size.

Tables 2-4 shows the percentages of establishments that hinder systems and regulations growth according to size. 
Table 7. Percentages of establishments that hinder systems and regulations growth according to size.

\begin{tabular}{llll}
\hline Problems & $\mathbf{1 - 5}$ employees & 6-49 employees & 50-250 employees \\
\hline Fees & $18 \%$ & $24 \%$ & $27 \%$ \\
Labor and labor system & $18 \%$ & $19 \%$ & $17 \%$ \\
Recruitment & $30 \%$ & $19 \%$ & $14 \%$ \\
The competition & $28 \%$ & $7 \%$ & $4 \%$ \\
Saudization & $15 \%$ & $11 \%$ & $10 \%$ \\
Issuing or renewing licenses & $14 \%$ & $9 \%$ & $12 \%$ \\
The bureaucracy & $21 \%$ & $14 \%$ & $19 \%$ \\
Government action & $25 \%$ & $20 \%$ & $15 \%$ \\
\hline
\end{tabular}

Source: Survey of the General Organization for Statistics for Small and Medium Enterprises (2017).

Table 7 above shows the percentages of establishments that hinder the systems and regulations of their growth by size by dividing them into three categories according to the number of workers. The first category employs 1-5 workers. The most important regulations and regulations that hinder their growth in fees, Followed by the bureaucracy with $19 \%$, while the obstacles to the labor system represented $17 \%$. The government measures constituted 15\%; the problems of recruitment were $14 \%$, followed by the obstacles to issuing or renewing the licenses by $12 \%$. Labor for Saudis is $10 \%$ and competition ranked last by $4 \%$.

The second category concerned institutions with a staff of between 6 and 49 workers. The most important obstacles were the fees which represented $24 \%$, while the governmental procedures accounted for $20 \%$, followed by the obstacles related to the labor system and the barriers to recruitment by $19 \%$ each. And the bureaucracy occupied a middle rank in these obstacles by $14 \%$, followed by obstacles to providing job opportunities for Saudis by $11 \%$, and then issuing or renewing licenses by $9 \%$ and finally competition by $7 \%$.

The third category, according to the classification of the General Organization for Statistics in the survey of small and medium enterprises with more than 250 workers, the most important obstacles related to the regulations and regulations in recruitment by $30 \%$, followed by direct competition by $28 \%$
And $25 \%$ and $21 \%$ respectively. Obstacles related to the labor system accounted for $18 \%$, the obstacles to job creation for Saudis by $15 \%$, and Issuance or renewal of licenses by $14 \%$.

The researcher finds that the clear disparity between the three categories of institutions divided by the number of employees is good and corresponds to the size differences within the classification of small and medium enterprises which fall into three categories but the problems remain similar to the three categories:

1. Fees.

2. Labor and labor system.

3. Recruitment.

4. The competition.

5. Employment of Saudis.

6. Issuing or renewing licenses.

7. The bureaucracy.

8. Government action.

\subsubsection{Obstacles Facing Enterprises According to the Survey of the Small and Medium Enterprises for the Year 2017}

The nature and specificity of small and medium enterprises in terms of small size, legal form, number of employees and other characteristics may be the reason for the obstacles encountered in all stages of their growth Table 8.

Table 8. Percentage of establishment facing obstacles during creation and start-up by size of establishment.

\begin{tabular}{|c|c|c|c|}
\hline Problems & 1-5 employees & 6-49 employees & 50-250 employees \\
\hline Access to Finance & $9 \%$ & $7 \%$ & $10 \%$ \\
\hline Land/Rent of Space & $15 \%$ & $17 \%$ & $5 \%$ \\
\hline Licenses \& Permits & $14 \%$ & $12 \%$ & $10 \%$ \\
\hline Security \& Stability & $0 \%$ & $0 \%$ & $0 \%$ \\
\hline Customs/Trade Laws \& Regulations & $9 \%$ & $7 \%$ & $4 \%$ \\
\hline Export/Trade with other countries & $7 \%$ & $3 \%$ & $1 \%$ \\
\hline Electricity Supply (without Interruption) & $3 \%$ & $7 \%$ & $6 \%$ \\
\hline Water Supply (without Interruption) & $3 \%$ & $5 \%$ & $10 \%$ \\
\hline Water Price & $2 \%$ & $3 \%$ & $2 \%$ \\
\hline Fuel Supply (without Interruption) & $2 \%$ & $2 \%$ & $1 \%$ \\
\hline Fuel Price & $19 \%$ & $14 \%$ & $6 \%$ \\
\hline Availability of Skilled Labor & $23 \%$ & $19 \%$ & $16 \%$ \\
\hline Labor Laws \& Regulations & $23 \%$ & $19 \%$ & $15 \%$ \\
\hline Government Inspection Procedures & $6 \%$ & $8 \%$ & $9 \%$ \\
\hline Access to Technical Support (Training \& Consulting Services) & $14 \%$ & $9 \%$ & $6 \%$ \\
\hline Government Procedures \& Bureaucracy & $16 \%$ & $16 \%$ & $15 \%$ \\
\hline
\end{tabular}

Source: Survey of the General Organization for Statistics for Small and Medium Enterprises (2017). 
Table 8 shows the obstacles faced by small and medium enterprises, which were divided into three categories according to the number of workers in the first category, which employs 1-5 workers. The main obstacles were the rise in electricity prices by $30 \%$, followed by the lack of trained manpower the problems related to labor laws and regulations and governmental and bureaucratic procedures have been obstacles to about $15 \%$ of the institutions in this category. Obstacles related to access to finance, along with obstacles to continuity of water supply without interruption, as well as obstacles to obtaining commercial licenses and permits (9\%).
The obstacles related to the continuity of electricity supply (without interruptions), as well as the obstacles to access to technical assistance (training and services), amounted to $6 \%$. Obstacles related to access to the site/rental of the building were $5 \%$ and the obstacles related to customs and trade regulations amounted to $4 \%$. Water prices constituted obstacles for about $2 \%$ of these establishments, followed by obstacles related to export/trade potential with other countries, S) for obtaining a telephone line, Internet and barriers (communications) have all been by $1 \%$ completely and there is a lack of security and stability-related obstacles.

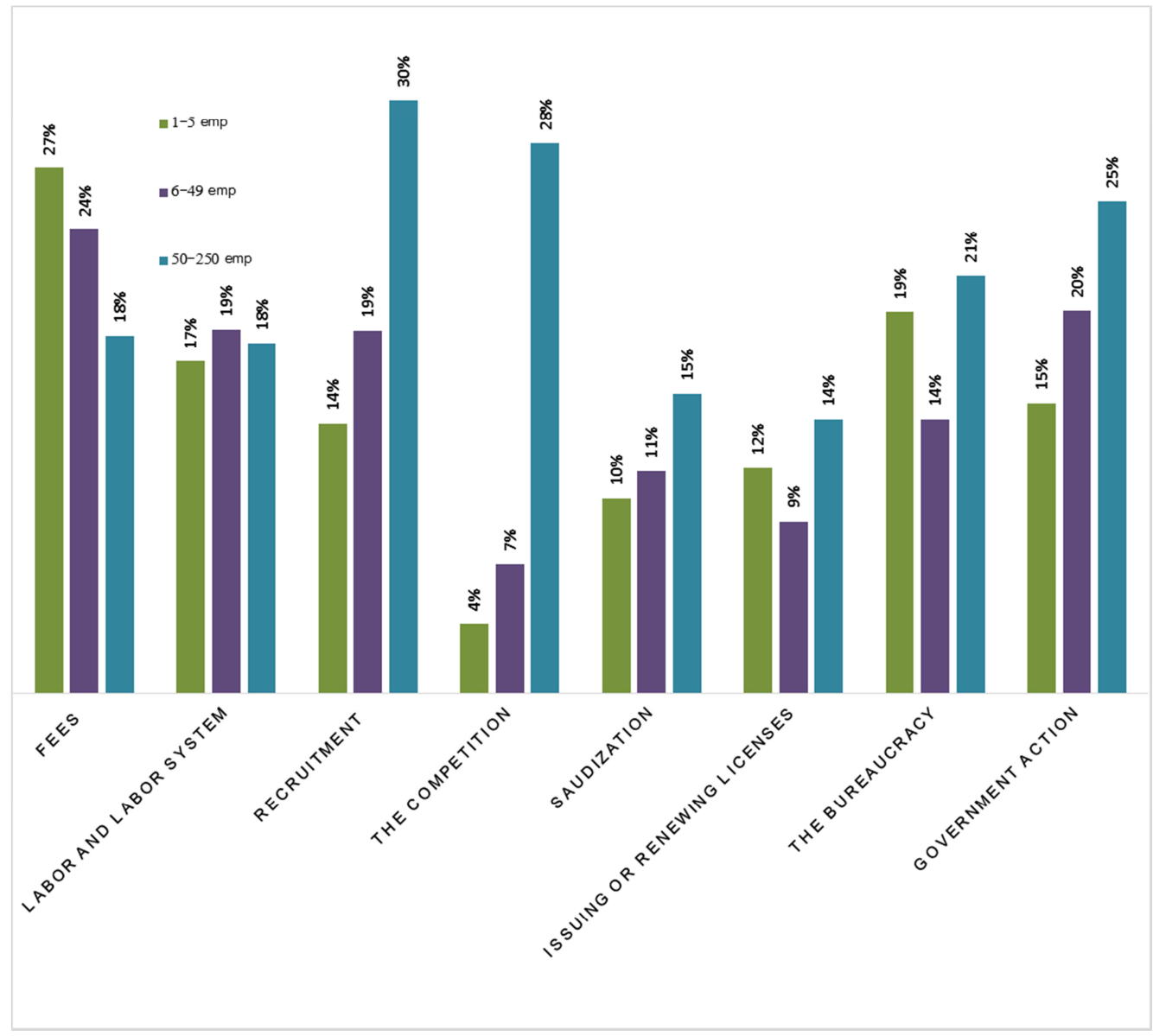

Source: Survey of the General Organization for Statistics for Small and Medium Enterprises (2017).

Figure 4. Percentage of establishment facing obstacles during creation and start-up by size of establishmen.

The second category concerned institutions with 6 to 49 workers. The most important obstacles facing them were the availability of trained manpower and labor laws and regulations at $19 \%$ each, followed directly by $17 \%$. Obstacles related to obtaining the site/rental of the building either Obstacles related to governmental and bureaucratic procedures were $16 \%$, while the obstacles related to fuel prices represented about $14 \%$ of the establishments in this category, followed by the special obstacles to obtaining the commercial licenses and permits which amounted to $12 \%$ Access to technical assistance (training and services) amounted to $9 \%$ of establishments in this category, while obstacles to official inspection were $8 \%$ followed by obstacles to access to finance of $7 \%$. Obstacles to customs and trade regulations and obstacles to the continuity of electricity supply (5\%). The obstacles related to the continuity of water supply (without interruptions) were $3 \%$ of establishments listed in this category, followed by water price barriers of $2 \%$. Obstacles to access to the telephone line and internet (Communications) have reached the barriers to security and stability in this category, as well as other groups, have been completely eliminated.

The third category according to the classification of the General Organization for Statistics in the survey of small and medium enterprises and the number of employees is more than 250 workers. The most important obstacles were the 
availability of trained manpower alongside labor laws and regulations by $23 \%$, followed by the obstacles related to fuel prices by $19 \%(16 \%)$. Obstacles related to access to the site/rental were $15 \%$, and the barriers to access to technical assistance (training and services) were 14\% And barriers to access to finance were $9 \%$, as were the barriers to trade regulations And customs barriers. Obstacles related to the prices of electricity and obstacles to export/trade potential with other countries amounted to $7 \%$ each. Obstacles to formal inspections of facilities amounted to $6 \%$. Obstacles related to the continuity of fuel supply (without interruptions) and obstacles to the continuity of electricity supply (Without interruptions), reaching 3\% per year, while $2 \%$ for water price barriers, continuous fuel supply (without interruptions), telephone and internet access (communications), and security and stability barriers in this category.

\subsubsection{SMEs Growth in Saudi Arabia}

The State and the private sector provide many advantages to help small and medium enterprises to grow and develop. According to the General Organization for Statistics, the following table shows the percentage of establishments that contribute to the growth of the regulations according to size:

Table 9. Percentage of establishments that systems and regulations contribute to growth by size.

\begin{tabular}{llll}
\hline Problems & $\mathbf{1 - 5}$ employees & $\mathbf{6 - 4 9}$ employees & $\mathbf{5 0 - 2 5 0}$ employees \\
\hline Government support and loans & $32 \%$ & $19 \%$ & $13 \%$ \\
Easy licensing & $18 \%$ & $29 \%$ & $45 \%$ \\
Vocational Localization (Saudization) & $16 \%$ & $10 \%$ & $10 \%$ \\
Electronic services & $67 \%$ & $36 \%$ & $18 \%$ \\
Vision 2030 & $13 \%$ & $15 \%$ & $14 \%$ \\
Training & $10 \%$ & $6 \%$ & $5 \%$ \\
\hline
\end{tabular}

Source: Survey of the General Organization for Statistics for Small and Medium Enterprises (2017).

Table 9 shows the percentages of establishments that contribute to the growth of the systems and regulations into three categories starting with the first category, which employs 1-5 workers. The most important of these systems, (20\%), followed by $2030(14 \%)$, governmental support and facilities $(13 \%)$, vocational training $(10 \%)$, and finally the training was $5 \%$.

The second category concerned institutions with a number of employees of between 6-49 workers. The electronic services were one of the systems which contributed $36 \%$ to the growth of the systems and the second was followed by the ease of issuing the licenses by $29 \%$ the contribution of Vision 2030 was about 15\%, 10\% was for vocational Saudization, and finally the training was $5 \%$.

The third category, according to the classification of the General Organization for Statistics in the survey of small and medium enterprises, which has more than 250 workers, was the most important regulations and regulations that contribute to its growth in electronic services by $67 \%$, followed by direct government support and loans by $32 \% 18 \%$ and $16 \%$ in favor of vocational resettlement (Saudization).

The contribution of Vision 2030 was about $13 \%$ and finally training by $10 \%$ through the previous analysis, the researcher believes that the regulations and regulations that have helped SMEs are:

1. Electronic services.
2. Ease of issuing permits.

3. Government support and loans.

4. Vision contribution 2030.

5. Saudization (employment of Saudis).

6. Training.

\subsubsection{The Most Important Financing Institutions for Small and Medium Enterprises in the Kingdom of Saudi Arabia}

There are many supporting and financing institutions for small and medium-sized enterprises in the Kingdom, ranging from government to private, including banks, funds and charitable foundations review them.

\subsubsection{SME Financing Program (Kafala)}

The program of financing the small and medium enterprises was establishing in accordance with the decision of His Excellency the Minister of Finance No. 1166 dated 04/05/1425 H. The program aims to overcome the obstacles of financing economically viable SMEs that do not have the ability to provide the required guarantees to the financing institutions. The establishment of the program to cover the percentage of the risk of the funding in the event of failure of the activity guaranteed. It is necessary to pay the financing or part thereof and to encourage banks to finance small and medium enterprises.

Table 10. The evolution of funding for projects during the period 2014-2017.

\begin{tabular}{|c|c|c|c|c|}
\hline Years & Number of guarantees & Value of guarantees & Value of funding & Number of establishments \\
\hline 2013 & 2,515 & 1.285 .457 & $2,348,125$ & 1,173 \\
\hline 2014 & 3.612 & 1.687 .900 & 3.461 .123 & 1,497 \\
\hline 2015 & 4,007 & $1,820,419$ & $3,723,281$ & 1,643 \\
\hline 2016 & 3,390 & $1,827,789$ & $3,557,400$ & 1711 \\
\hline Until the third quarter of 2017 & 1,219 & $1,350,209$ & $2,497,550$ & 1,309 \\
\hline
\end{tabular}

Source: Collecting the researcher from the annual reports to Kafala 2018. 
The table 10 above shows that there is an increasing growth in the number of guarantees, which in 2013 amounted to about 2515 guarantees and increased by $43 \%$ to 3612 guarantees for 2014 and then increased in 2015 to 4007 guarantees with an increase of $11 \%$. In 2016 at a rate, about $15 \%$ decline and continues to decline until the third quarter of 2017.

As for the value of guarantees, there is an increasing growth of them and in 2013 amounted to about 1.285.457 riyals. It increased by $31 \%$ to become 1.687 .900 riyals for the year 2014. It increased then in 2015 to become 1.820 .419 riyals by $8 \%$ growth. However, in 2016 has increased at a pace Declining to become 1.827 .789 riyals, an increase of about $4 \%$, and amounted to the end of the third quarter of the year 2017 about 1,350,209 riyals.

As for the value of the financing provided, in 2013 it amounted to about 2.348 .125 riyals and increased by $47 \%$ to become 3,461,123 riyals for the year 2014 and then increased in 2015 to become 3,723,281 riyals with growth of $7 \%$ and in 2016 decreased to 3.557 . 400 riyals by a decrease of about $4 \%$, and amounted to the end of the third quarter of the year 2017 about 2,497,550 riyals.

Comparing the number of funded enterprises, it was about 1173 establishments in 2013 and increased in 2014 to 1497 establishments with a growth rate of about $27 \%$. The number of establishments funded in 2015 amounted to 1643 establishments, an increase of $9 \%$ compared to the previous year. In 2016, there were 1711 establishments with a growth rate of approximately $4 \%$ compared to the previous year, while the number of establishments financed by the end of the third quarter of 2017 reached about 1309 establishments.

\section{Conclusions and Recommendations}

The study confirmed that the financing of small and medium enterprises could develop with the existence of the General Authority for Small and Medium Enterprises, which is basing on the division of institutions into three types (micro, small and medium) according to the employment standards and the size of revenues.

The study showed that the most important reasons for the lack of access to finance by small and medium enterprises are the lack of adequate guarantees in the lack of accounting records, the weakness of funding structures, inadequate lending standards, the failure to provide feasibility studies and the inability to prepare a credit file.

For the Saudi Arabian Monetary Authority, the study recommends:

1. The need for an encouraging policy for the financing of small and medium enterprises, with a unified definition, specifying a specific percentage of funding brackets to finance them, and establishing a legal and legislative basis and a specific mechanism for the development of SMEs.

2. Considering the establishment of specialized banks in the financing of these institutions according to time and sector, with the possibility of establishing the Bank of Trades and Crafts or the Bank of Small and Medium Industries.

\section{References}

[1] Report of the International Labor Organization (2017).

[2] Report of the United Nations Industrial Development Organization for Small Enterprises in Developing Countries (UNIDO), 2017.

[3] Khalil and Nqmoush (2010) d. Abdel Razek Khalil A. Adel Nqmoush Role of small and medium industries in achieving economic development - University of A Laghouat - Algeria.

[4] Islam Online (http://www.islamonline.net).

[5] Annual Report of the Arab Labor Organization (2008).

[6] The Journal of Human Sciences (www.ulum.nl http://) The importance of small and medium enterprises.

[7] Omar (2009) Dr. Mohamed Abdel Halim Omar, Head of Sheikh Sale Kamel Center for Islamic Economics at Al-Azhar University "Islamic Financing Methods for Small Enterprises".

[8] Al-Hiti (2009), Dr. Nawaf Abdulrahman Al-Hiti, "Small and Medium Industries in the GCC Countries, Current Status and Future Challenges".

[9] Riyadh Chamber of Commerce and Industry (2004), a study within the activities of the Riyadh Economic Forum towards sustainable economic development entitled "Small enterprises are engines of economic growth".

[10] C. L. Mann; Small and Midsize Enterprises in the United States and East Central Europe; Common Challenges in the 1990s, Oxford.

[11] Salama (2009) Small projects in the Kingdom of Saudi Arabia and its role in reducing unemployment.

[12] Al-Beltagy (2005), Dr. Mohamed El-Beltagy, Director of Sharia-compliant Banking Programs, Banking Institute, Saudi Arabian Monetary Agency (SAMA), "Proposed Formulas for Microfinance and Accounting Treatment of the Participation Formula".

[13] the Annual Conference of the Arab Academy of Sciences Banking and Finance, Hashemite Kingdom of Jordan, Amman.

[14] Ibrahim (2007) Dr. Badruddin Abdul Rahim Ibrahim, (Microfinance Requirements) Economist - Ministry of Finance Sultanate of Oman, Gulf Newspaper Miscellaneous series articles on microfinance and small and medium enterprises.

[15] Yassin (2008), Mahmoud Mohammed Yassin, Journal of Urban Dialogue No. 2311 "Small production and share capital by reference to the situation of Sudan".

[16] http://smeadvisorarabia.com.

[17] Saudi General Organization for Statistics conducts an annual survey of small and medium enterprises 2017.

[18] Vision of Saudi Arabia 2030. 